\title{
Effects of Ocimum basilicum extract on hematological and serum profile of male albino mice after $\mathrm{AlCl}_{3}$ induced toxicity
}

\author{
Ahmad Ali ${ }^{1}$, Muhammad Qasim², Muhammad Nazar Aftab ${ }^{1,3}$, Sheikh \\ Muhammad Azam ${ }^{1,4}$, Furhan Iqbal ${ }^{5}$, Shehla Akram ${ }^{1}$ and Muhammad \\ Zubair Hussain ${ }^{6 *}$ \\ 1. Department of Life Sciences, Islamia University Bahawal Pur-Pakistan \\ 2. Department of Bioinformatics \& Biotechnology, Government College University Faisalabad-Pakistan \\ 3. Department of Biology, Government Wallayat Hussain Islamia College, Multan-Pakistan \\ 4. University of Education, Dera Ghazi Khan Campus-Pakistan \\ 5. Institute of Pure and Applied Biology, Bahauddin Zakariya University, Multan-Pakistan \\ 6. Department of Zoology, Government Emerson College, Multan-Pakistan \\ *Corresponding author's email: zubairhussainpk@yahoo.com \\ Citation \\ Ahmad Ali, Muhammad Qasim, Muhammad Nazar Aftab, Sheikh Muhammad Azam, Furhan Iqbal, Shehla Akram \\ and Muhammad Zubair Hussain. Effects of Ocimum basilicum extract on hematological and serum profile of male \\ albino mice after $\mathrm{AlCl}_{3}$ induced toxicity. Pure and Applied Biology. Vol. 6, Issue 2, pp505-510. \\ http://dx.doi.org/10.19045/bspab.2017.60050
}

Received: $13 / 01 / 2017$

Revised: 20/03/2017

Accepted: $26 / 03 / 2017$

Online First: 30/03/2017

\section{Abstract}

The present study was aimed to investigate the recovery effects of leave extract of Ocimum basilicum against $\mathrm{AlCl}_{3}$ induced toxicity. The trial was performed on adult male albino mice (Mus musculus). The experimental animals were randomly divided into three groups i.e. control, T1 and T2 with six animals in each group. Animals in control group received no treatment and were provided with normal saline. Both treatment groups T1 and T2 were orally administered with $80 \mathrm{mg} / \mathrm{kg}$ body weight of $\mathrm{AlCl}_{3}$ for 16 days. After that animals in $\mathrm{T} 1$ and $\mathrm{T} 2$ groups were administered $100 \mathrm{mg} / \mathrm{kg}$ body weight and $200 \mathrm{mg} / \mathrm{kg}$ body weight respectively of Ocimum basilicum extract for 15 days. Several of the important hematological and serological parameters were measured. There was a significant increase in lymphocyte count and a significant decrease in neutrophil count in both T1 and T2 groups. There was a significant increase in red blood cells and platelet count while mean corpuscular haemoglobin was significantly decreased in T1 group. Alanine transaminase was significantly increased while serum creatinine was decreased in both T1 and T2 groups. It is concluded that Ocimum basilicum extract influenced several hematological and serological parameters in male albino adult mice after $\mathrm{AlCl}_{3}$ induced toxicity. Keywords: AST; Creatinine; Cholesterol; Medicinal plants; Toxicity

\section{Introduction}

There are several metal that have high concentration in the environment and are toxic for human beings as well as other living organisms $[1,2]$. Aluminium $(\mathrm{Al})$ is one of such metals frequently distributed through earth crust [3]. It is an integral component of many medicines, food additives and also added to drinking water for purification purposes [4]. Several 
sources of aluminium in daily life include spices, yellow cheese, aluminum ware, corn, salt, cosmetics, herbs, tea, antacid drugs and tooth paste [5]. Aluminium accumulates in several mammalian tissues including liver, kidney, heart, bone, blood, and brain [6]. The accumulated aluminium exerts toxic effects all over the human body especially central nervous system [7]. It induces microcytic anemia, directly effects haematopoisis; causes oxidative stress in brain tissue [8]; and is a contributing factor in Alzheimer's disease [9].

Traditionally several plants of Indo-Pak subcontinent have used a medicine since ages. Such medicinal plants may exert variable effects on human beings $[10,11]$. Ocimum basilicum L. (Basil) of family Lamiaceae has also been used as medicinal plant since times. Ocimum basilicum comprises of phenolic compounds that act free radical-scavengers, powerful antioxidants and metal chelators $[12,13]$. It has also been used to cure several digestive disorders including nausea, poor digestion, abdominal cramps, gastro-enteritis, chronic diarrhea, dysentery; psychotic disorders like insomnia and depression as well as migraine [14]. The present study aimed to evaluate the effects of the extract from Ocimum basilicum on recovery response in adult albino male mice after $\mathrm{AlCl}_{3}$ induced toxicity.

\section{Materials and methods}

\section{Experimental design}

The experiment was conducted on male albino mice (aged approximately $8 \pm 1$ weeks) obtained from the laboratory of Government Post Graduate College Gojra, Toba Tek Singh distrit, Pakistan. This experiment was carried out at animal house, Bio Park Bahaudin Zakaryia University. Mice were reared in small cages (locally manufactured) provided with wooden chips. Water and food were made available ad libitum. Room temperature $\left(22 \pm 1^{0} \mathrm{C}\right)$ was maintained along with a regular light/dark cycle in a ratio of 14:10. All the animal handling procedures and experimental protocols were approved by ethical review board of Institute of Pure and Applied Biology, Bahauddin Zakariya University Multan, Pakistan. The animals were divided randomly into 3 groups i.e. control, T1 and $\mathrm{T} 2$ ( $\mathrm{N}=6$ in each group). The control group received normal saline, whereas experimental groups i.e. T1 and T2 were orally administered $80 \mathrm{mg} / \mathrm{kg}$ body weight of $\mathrm{AlCl}_{3}$ for 16 days. After that, animals in T1 group were orally administered with 100 $\mathrm{mg} / \mathrm{kg}$ body weight of Ocimum basilicum extract, and animals in T2 group were orally administered with $200 \mathrm{mg} / \mathrm{kg}$ body weight of Ocimum basilicum extract for 15 days.

\section{Leave extract of Ocimum basilicum}

The leaves of Ocimum basilicum were collected from plants grown in local fields of Multan. The leaves were made free of adulterated material through manual picking, washed and shade dried. Dried leaves were powdered with the help of Waring Blender. $300 \mathrm{~g}$ of powdered leaves was soaked in $70 \%$ aqueous ethanol $(\mathrm{v} / \mathrm{v})$ and $30 \%$ distilled water for 7 days in amber colored glass bottles. The bottles were shaken at least 3-4 times per day. The gas was removed by opening lid of the bottle after every shake and then was tied tightly again. The soaked leaves material was filtered first using a double layered muslin cloth to remove vegetative debris, and finally through Whatman filter paper (No. 4). The residues were re-soaked in $70 \%$ aqueous-ethanol and $30 \%$ distilled water and the procedure was repeated twice. The obtained crystal clear filtrates were evaporated on a rotatory evaporator (R-210, BUCHI, Switzerland) under reduced pressure $(-760 \mathrm{mmHg})$ and temperature $(37$ $\left.{ }^{\circ} \mathrm{C}\right)$ to a concentrated paste. The thick pastes were kept in their respective petri plates and stored at $4^{\circ} \mathrm{C}$ until further use. 
Blood and serum collection After treatment, mice were euthanized by $3 \%$ Isoflurane solution and the blood was collected from retro-orbital sinus and cardiac puncture in two test tubes. One test tube was added with anticoagulant for hematological analysis and the other without anticoagulant for serum analysis. The serum collected was stored at $-20^{\circ} \mathrm{C}$ for further analysis. Complete blood count consisting of several parameters including mean corpuscular volume (MCV), mean corpuscular hemoglobin $(\mathrm{MCH})$, mean corpuscular hemoglobin concentration (MCHC), packed cell volume (PVC), hemoglobin level (HB), total red blood cells (RBC), white blood cell count (WBC), total lymphocytes, neutrophil count and total platelets count was determined in treated and untreated albino mice by using hematology analyzer (FMI- 6180, Jiangsu, China).

Serum biochemical parameters including Alanine transaminase (ALT), Aspartate transaminase (AST), Cholesterol, triglycerides, creatinine and Total protein were analyzed in serum samples by using automatic analyzer (Hitachi 902, Japan) following the instructions of diagnostic kit manufacturers.

\section{Statistical analysis}

All the data is expressed as means \pm standard deviation (SD). The data obtained in this analysis was subjected to two sample t-test for comparing hematological and serum parameters of control and treatment groups, using statistical package Minitab (version 17, Pennsylvania).

\section{Results}

\section{Hematological parameters}

In T1 group, RBC and PLT and LYM showed significant increase compared to control group; while $\mathrm{MCH}$ and NEUT showed significant decrease compared to control group. The WBC, HGB, HCT, MCV and $\mathrm{MCHC}$ showed no significant changes in T1 group compared to control group. In T2 group, LYM showed significant increase while NEUT showed significant decrease compared to control group. There was no significant change in RBC, WBC, HGB, HCT, MCV, MCH, MCHC, and PLT compared to control group (Table 1).

Table 1. Effect of administration of Ocimum basilicum extract on hematological profile of male albino mice for recovery response after $\mathrm{AlCl}_{3}$ induced toxicity

\begin{tabular}{|c|c|c|c|}
\hline \multirow[t]{2}{*}{ Parameters } & \multicolumn{3}{|c|}{ Groups } \\
\hline & Control & T1 & $\mathbf{T 2}$ \\
\hline RBC $\left(\times 106 \mu L^{-1}\right)$ & $4.715 \pm 0.30$ & $6.047 \pm 0.33 *$ & $5.06 \pm 0.51$ \\
\hline WBC $\left(x 103 \mu L^{-1}\right)$ & $2.733 \pm 0.28$ & $3.250 \pm 0.27$ & $3.50 \pm 1$ \\
\hline HGB $\left(\right.$ gdL $\left.^{-1}\right)$ & $8.57 \pm 0.69$ & $10.30 \pm 0.56$ & $8.12 \pm 0.70$ \\
\hline HCT (\%) & $25.70 \pm 2.1$ & $31.38 \pm 1.9$ & $26.45 \pm 3.2$ \\
\hline $\operatorname{MCV}(f \mathbf{L})$ & $49.08 \pm 0.88$ & $51.82 \pm 1.1$ & $51.90 \pm 1.7$ \\
\hline MCH (pg) & $18.067 \pm 0.34$ & $17.050 \pm 0.12 *$ & $16.30 \pm 0.89$ \\
\hline MCHC $\left(\mathrm{gdL}^{-1}\right)$ & $33.683 \pm 0.20$ & $32.95 \pm 0.59$ & $31.72 \pm 2.3$ \\
\hline PLT $\left(x 103 \mu L^{-1}\right)$ & $164.2 \pm 29$ & $336 \pm 53 *$ & $216 \pm 50$ \\
\hline LYM (\%) & $65.50 \pm 2.4$ & $83.38 \pm 3.8 * *$ & $84.55 \pm 2.7 * * *$ \\
\hline NEUT (\%) & $30.50 \pm 2.2$ & $16.62 \pm 3.8^{*}$ & $15.45 \pm 2.7 * *$ \\
\hline
\end{tabular}

$* \mathrm{P}<0.05, * * \mathrm{P}<0.01, * * * \mathrm{P}<0.001$ (two sample student t-test)

\section{Serological parameters}

In T1 group, AST showed significant increase; while cholesterol and creatinine 
showed significant decrease compared to control group. Whereas, ALT, triglyceride and total protein showed no significant change compared to control group. In T2 group, AST showed significant increase compared to control group; while creatinine showed significant decrease compared to control group. ALT, cholesterol, triglyceride and total protein showed no significant change compared to control group (Table 2).

Table 2. Effect of administration of Ocimum basilicum extract on blood serum profile of albino male mice for recovery response after $\mathrm{AlCl}_{3}$ induced toxicity

\begin{tabular}{|l|c|c|c|}
\hline \multirow{2}{*}{ Parameters } & \multicolumn{3}{|c|}{ Groups } \\
\cline { 2 - 4 } & Control & T1 & T2 \\
\hline AST $\left(\mu \mathrm{L}^{-1}\right)$ & $300.7 \pm 28$ & $1338 \pm 158^{* *}$ & $770 \pm 149^{*}$ \\
\hline ALT $\left(\mu \mathrm{L}^{-1}\right)$ & $285 \pm 45$ & $593 \pm 169$ & $315 \pm 89$ \\
\hline Cholesterol $\left(\mathrm{mgdL}^{-1}\right)$ & $159.2 \pm 12$ & $120 \pm 7.3^{*}$ & $107 \pm 28$ \\
\hline Triglyceride $\left(\mathrm{mgdL}^{-1}\right)$ & $128 \pm 26$ & $126 \pm 15$ & $158 \pm 60$ \\
\hline Creatinine $\left(\mu \mathrm{L}^{-1}\right)$ & $0.433 \pm 0.042$ & $0.1317 \pm 0.03^{* * *}$ & $0.100 \pm 0.025^{* * *}$ \\
\hline Total Protein $\left(\mathrm{gdL}^{-1}\right)$ & $6 \pm 0.43$ & $6.717 \pm 0.17$ & $5.20 \pm 0.62$ \\
\hline
\end{tabular}

$* \mathrm{P}<0.05, * * \mathrm{P}<0.01, * * * \mathrm{P}<0.001$ (two sample student $\mathrm{t}$-test)

\section{Discussion}

Our findings demonstrated that aqueous ethanolic leaf extract of Ocimum basilicum at low dose caused significant increase in RBC count. This is in agreement with the results from previous research work. Aqueous leaves extract of Ocimum sanctum in Wistar albino rats after lead induced toxicity [15], aqueous leaves extract of Ocimum gratissimum [16] and methanolic leaf extract of Ocimum basilicum in male swiss albino mice after benzene induced toxicity [17] increased RBC count. In normal conditions, anoxia in local tissues apparently leads to the synthesis of a glycoprotien called erythropoietin which stimulates enhanced formation of erythrocytes [18]. It may be suggested that Ocimum sanctum, Ocimum gratissimum and Ocimum basilicum leaves extract might contain an erythropoietin like agent that could increase production of erythrocytes.

Our results also demonstrated a significant increase in lymphocyte count. Previously, it has been reported that methanolic leaf extract of Ocimum basilicum in male Swiss albino mice toxified with benzene [17]; and in Wistar albino rats [19] significantly increased the lymphocyte count. it has been reported that Ocimum basilicum modulate the cell-mediated as well as humoral immune response that could be due to the presence of flavonoids and terpenoids [20]. Contrary to this, ethanolic leaf extract of Ocimum basilicum significantly decreased neutrophil count. This is consistent with results from previous studies in which methanolic extract from leaves of Ocimum basilicum in Wistar albino rats [19]; and ethanolic extract of Ocimum gratissimum in wistar rats [21] significantly decreased neutrophils count. Ethanolic extracts from leaves of Ocimum basilicum with low dose caused a significant decrease in the serum cholesterol level in male albino mice. Similar results have also been reported with aqueous extract from leaves of Ocimum basilicum [22] and by long term consumption of leaves of Ocimum gratissimum [23] in rats significantly decreased the serum cholesterol level. A study has reported that flavoniods found in Ocimum gratissimum decrease cholesterol [24].

Ethanolic leaf extract of Ocimum basilicum caused significant increase in AST serum 
level in male albino mice. Our findings are in agreement with the results from previous studies in which extracts of Ocimum basilicum [25] and Ocimum gratissimum [26] significantly increased serum level of AST. It could be suggested that Ocimum gratissimum and Ocimum basilicum leaf extracts might have similar chemical constituents as these plants belong to the same genera and caused enhancement in the serum AST level. However, results are also contradictory with another study in which aqueous leaf extracts of Ocimum basilicum significantly decreased AST and ALT serum level [22]. This difference might be due to difference in pretreatment as we used $\mathrm{AlCl}_{3}$ in our experiment while paracetamol was used as pretreatment by Khoun [22].

Our results also demonstrated that ethanolic leaf extract of Ocimum basilicum significantly decreased serum creatinine level. These findings are in agreement with the previous results which demonstrate that aqueous extracts of Ocimum gratissimum in wistar albino rats [27], Ocimum basilicum [28], and ocimum sanctum in mice [21] significantly decreased serum creatinine level. This decrease in serum creatinine level might be due to nephroprotective effects of Ocimum.

\section{Conclusions}

Leave extract of Ocimum basilicum influenced several hematological parameters including red blood cell count, mean corpuscular hemoglobin, lymphocyte and neutrophil count in male albino adult mice after $\mathrm{AlCl}_{3}$ induced toxicity. Similarly, several serological parameters including aspartate transaminase, cholesterol and creatinine were also influenced by oral administration of the leave extract of Ocimum basilicum.

\section{Authors' contributions}

Conceived and designed the experiments: A Ali \& F Iqbal; Performed the experiments: MN Aftab \& SM Azam; Analyzed the data:
MN Aftab \& S Akram; Contributed reagents/materials/analysis tools: F Iqbal \& A Ali; Wrote the paper: MZ Hussain, MN Aftab, M Qasim \& A Ali.

\section{References}

1. Hounkpatin ASY, Johnson RC, Guédénon P, Domingo E, Alimba CG, Boko M \& Edorh PA (2012). Protective Effects of Vitamin C on Haematological Parameters in Intoxicated Wistar Rats with Cadmium, Mercury and Combined Cadmium and Mercury. Int Res J Biol Sci 1(8): 76-81.

2. Akinyeye AJ \& Okorie TG (2012). Heavy Metal Studies of Industrial Effluent on Alaro Stream Sediment. Int Res J Biol Sci 1(6): 1-9.

3. Greenwood NN \& Earnsha WA (1997). Chemistry of the Elements. 2nd Ed. 910 p.

4. Buraimoh AA, Adeniyiojo S, Ambolu JO \& Adebisi SS (2012). Effects of Aluminium Chloride Exposure on the Cerebral Cortex of Adult Wistar Rats Were Not Transferable to the Offspring. Am Int $J$ Contemp Res 2(8): 294-303.

5. Abbas Ali, Zhila T \& Farshad N (2005). Developmental Toxicity of Aluminium from High Doses of $\mathrm{AlCl}_{3}$ in Mice. The $J$ Appl Res 5: 575-579.

6. Al-kahtani MA (2010). Renal damage mediated by oxidative stress in mice treated with aluminum chloride: Protective effect of Taurine. J Biol Sci 10(7): 584-95.

7. Dominigo JL (1995). Reproductive and developmental toxicity of aluminium: a review. Neurotoxicol Teratol 17: 515-521.

8. Swartz R, Dombrouski J, BurnatowskaHledin M \& Mayor G (1987). Microcytic anemia in dialysis patients: reversible marker of aluminum toxicity. Am J Kid Dis 9: 217-223.

9. Campbell A (2002). The potential role of aluminium in Alzheimer's disease. Nephrol Dial.

10. Agbogidi OM, Obi-iyeke GE \& OLISA AC (2014). Health and Food Values of Scent Leaf (Ocimum gratissimum L.). World $J$ Biol Med Sci 1(4): 30-39.

11. Zereen A, Khan Z \& Ajaib M (2013). Ethnobotanical evaluation of the shrubs of 
Central Punjab, Pakistan. Biologia (Pakistan) 59 (1): 139-146.

12. Sundarraju D, Anbu J, Reeta R, Senthilkumar KI \& Anjana A (2014). Pharmacognostical and phytochemcial investigation of ethanolic extract on leaves of Ocimum basilicum. Int J Pharma Chem Biol Sci 4(1): 194-200.

13. Sgherri CS, Cecconami C, Pinzino F, Navari-Izzo \& Izzo R (2010). Levels of antioxidants and nutraceuticals in basil grown in hydroponics and soil. Food Chem 123: 416-422.

14. Kaya I, Yigit N \& Benli M (2008). Antimicrobial activity of various extracts of Ocimum basilicum and observation of the inhibition effect on bacterial cells by use of scanning electron microscopy. Afr $J$ Tradition Comp Alter Medicine 5(4): 363 369.

15. Karamala SK, Sri L, Anjaneyulu Y, Chandra STS, SreeniVasulu D \& Pidugu AP (2011). Hematobiochemical changes of lead poisoning and amelioration with Ocimum sanctum in Wistar albino rats. $J$ Vet World 4(6): 260-263.

16. Ofem OE, Ani EJ \& Eno AE (2012). Effect of aqueous leaves extract of Ocimum gratissimum on hematological parameters in rats. Int J Appl Basic Med Res 2(1): 3842.

17. Saha S, Mukhopadhyay MK, Ghosh PD \& Nath D (2012). Effect of methanolic leaf extract of Ocimum basilicum on benzeneinduced hematotoxicity in mice: evidencebased complementary and alternative medicine 1-7.

18. Bowman WC \& Rand MT (1980). Textbook of pharma: Drugs affecting coagulation, fibrinolysis, haematopoiesis and the functioning of blood cells. Oxford Blackwell publishers. pp. 21.1-21.53.

19. Jeba RC, Vaidyanathan $R$ \& Rameshkumar G (2011). Efficacy of Ocimum basilicum for immunomodulatory activity in Wistar albino rat. Int $J$ Pharma Pharmaceut Sci 3(4): 199-203.
20. Mediratta PK, Sharma KK \& Singh S (2002). Evaluation of immunomodulatory potential of Ocimum sanctum seed oil and its possible mechanism of action. $J$ Ethnopharmacology 80: 15-20.

21. Jimoh OR, Olaore J, Olayaki LA, Olawepo AO \& Biliaminu SA (2008). Effects of aqueous extract of Ocimum gratissimum on haemotological parameters of Wistar rats. J Biokemistri 20: 33-37.

22. Khoun OS (2012). Pharmacological effect of aqueous leaves of extract of Ocimum basilicum against liver toxicity induced by acetaminophen in male rats. Thi-Qar $J$ Agr Res 1(1): 13-27.

23. Iweala EEJ \& Obidoa O (2010). Studies on some biochemical and histological changes associated with long term consumption of leaves of Ocimum gratissimum in male rats. Am J Food Tech 5(6): 376-384.

24. Anderson JW, Diwadkar VA \& Bridges SR (1998). Selective effects of different antioxidants on oxidation of lipoproteins from rats. Soc Exp Biol Med 218: 376381.

25. Essien EB, Onyeike EN, Ugbeyide DE \& Eneke IC (2012). Effects of aqueous extract of Ocimum basilicum leaves on some hematological and biochemical parameters of Wistar albino rats. Can J Sci Indus Res 3(5): 256.

26. Arfa MM \& Rashed AM (2008). The modulative biochemical effect of extract of Ocimum gratissimum as anti-oxidant on diabetic albino rats. Egy J Comp Path Clinic Pathol 21(3): 69-87.

27. Arhohgro EM, Anosike EO \& Uwakwe AA (2012). Ocimum gratissimum aqueous extract enhances recovery in cisplatin induced nephrotoxicity in albino Wistar rats. Int J Drugs and Dis 1(5): 129-142.

28. Yacout GA, Elguindy NM \& El Azab EF (2012). Hepatoprotective effect of basil (Ocimum basilicum) on $\mathrm{CCl}_{4}$-induced liver fibrosis in rats. Afr J Biotech 11(90): 15702-15711. 